\title{
BRCA3 Gene
}

National Cancer Institute

\section{Source}

National Cancer Institute. BRCA3 Gene. NCI Thesaurus. Code C20779.

Human BRCA3 gene is located in the vicinity of $13 q 21$ the size of this phenotypic locus is not reported. This gene has no known product and may play a role in tumor suppression. Mutation of this locus is associated with breast cancer. 